\title{
DISCURSOS SOBRE A LEITURA E O LEITOR: A CONTRADIÇÃO QUE ENSINA
}

\author{
Discourses about reading and reader: \\ the contradiction that teaches
}

\author{
Maria Ester Vieira de Sousa*
}

\begin{abstract}
RESUMO
Objetivo nesse artigo retomar, no que se refere a nossas pesquisas, a discussão sobre leitura e leitor, circunscrevendo esse debate à formação do leitor na escola a partir do que os professores dizem acerca do aluno leitor. A fim de formular algumas implicações teórico-metodológicas, analisei as concepções de leitura e de leitor que o discurso do professor põe em circulação. Para tanto, utilizei dados coletados a partir de entrevistas realizadas com professores de escolas públicas e privadas do município de João Pessoa-PB, Brasil. Foram estabelecidos dois recortes: primeiro, analisei depoimentos de professores do Ensino Médio; segundo, os dados analisados referem-se ao momento da entrevista em que os professores foram convidados a falar sobre os alunos enquanto leitores. As perguntas formuladas direcionaram as respostas especificamente para a leitura do texto literário e, ao mesmo tempo, buscaram recuperar as expectativas que se formulam em relação à recepção desse texto. Esse estudo revela a existência de um discurso incansavelmente reeditado: a leitura concebida sob o signo de uma avaliação ou valoração determinada por critérios que antecedem o contato do leitor com o texto. Nessa perspectiva, as conclusões apontam para a necessidade de aprofundar, no contexto atual, o conceito de leitor, de leitura correta e o papel do professor como formador de leitores.
\end{abstract}

Palavras-chave: discurso do professor; função da leitura; concepção de leitor.

\footnotetext{
*Universidade Federal da Paraíba.
} 


\begin{abstract}
My aim in this paper is to return to the discussion about reading and readers, limiting this debate to the formation of readers at school, and taking as a starting point what teachers say about reader-learners. In order to formulate some theoreticalmethodological implications, I analyzed the concepts of reading and reader that are put in circulation by the teacher's discourse. To do so, I used data collected from interviews with teachers of public and private schools of João Pessoa, Paraíba, Brazil. Two outlines were determined: first, the interviews were conducted with secondary school teachers; second, data analyzed refers to the moment of the interview when teachers are asked to talk about the students as readers. The questions directed teachers' answers specifically towards literary reading, in addition to attempting to evoke their expectations in relation to the reception of the text by the students. This study revealed the existence of an unremittingly reedited discourse: the reading conceived under the sign of an evaluation or a valuation determined by criteria preceding the reader's contact with the text. In this perspective, this paper points towards the need to better understand, within the current context, the concept of reader and correct reading, as well as to better define the role of the teacher as the one who forms readers.
\end{abstract}

Keywords: teacher's discourse, function of reading, conception of reader.

\title{
1. INTRODUÇÃo
}

A discussão sobre os aspectos teórico-metodológicos da leitura enquanto conteúdo de ensino já representa um capítulo significativo da história do ensino no Brasil. Ainda assim, a discussão se mantém atual, como a denunciar a falta de algo e a assinalar que ainda há o que dizer. Nesse sentido, objetivo retomar essa temática a partir do discurso do professor acerca do aluno leitor, buscando refletir teoricamente sobre as funções da leitura, as concepções de leitor e os modos de ler que esse discurso põe em movimento. Para tanto, analisarei dados coletados a partir de entrevistas re- 
alizadas com professores de escolas públicas e privadas do município de João Pessoa-PB ${ }^{1}$, confrontando-os com outros discursos sobre a leitura e o leitor. Como se trata de uma pesquisa mais ampla, para esse trabalho foram estabelecidos recortes a partir de entrevistas, em que os professores são convidados a falar sobre os alunos enquanto leitores. Basicamente, as perguntas que orientaram esse momento foram as seguintes: "Qual a recepção dos alunos em relação ao texto literário? Gostam, não gostam?" e "Para você, o que os alunos gostam de ler?". Essas perguntas direcionam as respostas especificamente para a leitura do texto literário e, ao mesmo tempo, recuperam, implicitamente, as expectativas criadas em relação à recepção desse texto.

Considerando a natureza das perguntas formuladas, é preciso, inicialmente, esclarecer os pressupostos que as sustentam. Primeiro, concebo que a condição de aluno implica necessariamente a leitura, visto que esta surge no interior da escola não apenas como conteúdo de ensino (na disciplina de Língua Portuguesa), mas como condição de aprendizagem de todos os outros conteúdos escolares (matemática, ciências, história, geografia etc.). Ler é, portanto, uma ação correlata da função aluno, ainda que o professor, em geral, afirme o contrário, ou mesmo que o aluno afirme não ler. Segundo, defendo que existem leituras realizadas por prazer e aquelas que respondem a uma obrigação, escolar ou não (SOUSA, 2008, 2009). Nesse sentido, acredito que o discurso de que o aluno não lê "trapaceia" com a própria realidade da leitura na escola e, principalmente, com a realidade da leitura na sociedade atual, em que a condição de leitor passou a ser um passaporte para o sujeito. Consequentemente, esse discurso de que o aluno não lê espelha uma das contradições de que falarei posteriormente.

Do ponto de vista teórico-metodológico, sigo a perspectiva de trabalhos que concebem a leitura como práticas social e cultural, a exemplo de Michel de Certeau (1984) e Roger Chartier (2007, 2001, 1999, 1999b). Do ponto de vista analítico, procurarei identificar, em depoimentos de professores, procedimentos linguísticos que possibilitem recuperar as condições de produção desse discurso, buscando, inclusive, a sua filiação a discursos que, aparentemente, vêm de outros lugares, mas que constroem sentidos equivalentes e mantêm um sentido único para as noções de leitura e leitor. Nessa perspectiva, parto da compreensão teórica de que o discurso, ao mesmo tempo em que revela o trabalho do sujeito sobre a língua, também revela a

1 Os dados que serão objeto de análise fazem parte do corpus da pesquisa "Práticas escolares de leitura e discursos sobre a leitura", por mim coordenada, e que em 2009 e 2010 contou com a participação das alunas bolsistas do PIBIC/CNPq/UFPB Raquel Monteiro da Silva e Ruth Ellen Dutra. Nesse período, realizamos entrevistas com professores e alunos, enfocando os modos de leitura do texto literário na escola e as preferências dos alunos leitores. 
própria constituição desse sujeito (Pêcheux, 1997), marcada pelos efeitos de identificação do sujeito com interpretações produzidas ao longo de seu discurso. Desse modo, a noção de interdiscurso, enquanto memória do dizer, tal como formulada em Pêcheux (1997), será uma referência teórica, implícita ou explicitamente, requerida. Passemos, então, às análises.

\section{Discursos SOBRE O ALUNO-LEITOR}

Iniciarei essa discussão trazendo trechos do discurso de professores em que eles falam do outro (o aluno) ${ }^{2}$ :

E: eh... o que você acha/ qual a recepção dos alunos em relação ao texto literário?

P1: ah... uma frieza muito grande, né? Os jovens de hoje geralmente eles não gostam de ler e a dificuldade maior é encontrar essa satisfação e esse prazer na leitura porque foi passado para o jovem né? aquelas leituras fortes em vez da de criança num é? Eu creio que um aluno, uma aluna, né? traga alguns traumas de leitura porque lê por obrigação. (grifos meus)

P2: De modo geral? eles gostam muito de contos, agora não gostam de ler nada, diga-se de passagem, até os próprios textos do livro didático é com uma preguiça muito grande (ênfase) quando a gente...vai puxando (grifos meus).

Observemos que, nesses recortes, denuncia-se a ausência do leitor pela relação entre gostar e não gostar de ler. Parece que, num primeiro momento, pensamos sempre a leitura sob o signo do prazer, ou seja, a leitura está sempre associada a uma prática que deve ser desenvolvida sob o manto de uma positividade que precisa ser reconhecida e assimilada pelo sujeito-leitor. Assim concebida, não basta ler, é preciso gostar de ler. Por isso, a preguiça, como um dos pecados capitais, não pode imiscuir-se nessa prática. Além disso, é preciso reconhecer nesses depoimentos o signo da contradição, explicitamente representado em "eles gostam muito de contos, agora não gostam de ler nada" (depoimento de P2). O que essa contradição - materializada linguisticamente em "gostam... não gostam" - revela? Ainda é cedo para responder. Tentaremos situar essa discussão recorrendo, inicialmente, a outros discursos que também associam a leitura ao ato de amor.

2 Os professores foram identificados por letras e números (P1, P2, P3... por ordem de apresentação dos recortes) com o objetivo apenas de distinguir os diferentes sujeitos que falam. O entrevistador foi identificado, quando se fez necessário, por E. 
A partir da perspectiva aqui assumida, lembramos que o discurso de um povo inculto em função da ausência da leitura (ou da ausência de amor pela leitura) tem uma tradição que, na boca (ou na caneta) do próprio brasileiro, pode ser encontra no século XIX, para não ir tão longe. Vejamos um exemplo. No livro $O$ ensino público, cujo prefácio é de 1873, Antônio de Almeida Oliveira ${ }^{3}$ escreve, logo no primeiro capítulo, sobre "O Brasil e sua ignorância", sobre o Brasil "[...] que não trabalha porque é ignorante" (OLIVEIRA, [1873] 2003, p. 43), condição expressa pelo autor em dados que demonstram, por um lado, o número de iletrados e analfabetos e, por outro, os parcos recursos financeiros para investimento na "cultura intelectual do povo", resultando em poucas escolas (e poucos "escolares"), poucos museus, bibliotecas etc..

Como se não bastasse a carência de instituições promotoras de instrução, o autor ressalta que as que existem, a exemplo das bibliotecas, são de pouca utilidade,

[...] pois o povo dessa terra não ama a leitura, nem acredita nas suas vantagens. Poucas são as pessoas que freqüentam as bibliotecas, e essas mesmas, na sua maior parte, não com o fim de se ilustrar, mas de se distrair, pelo que só procuram livros de literatura. Os livros de ciências, os que tratam de coisas sérias, os que podem espalhar idéias úteis, esses não lhes agradam, são aborrecidos ou maçantes, como ordinariamente se diz. (OLIVEIRA, [1873] 2003, p. 51-52). (grifos nossos)

Voltemos, então, aos depoimentos dos professores para articular esses dizeres. Observemos que o primeiro professor (P1) apresenta como um dos motivos para o aluno não gostar de ler o contato inicial com "aquelas leituras fortes em vez da de criança”, capazes de gerar traumas. Portanto, o problema aponta para o objeto da leitura, aquilo que é dado a ler. No segundo depoimento, $\mathrm{P} 2$ refere-se ao modo de ler, recuperando algo já posto no primeiro: a leitura deve ser feita com alegria, com entusiasmo, com satisfação, modos específicos de ler que o professor lamenta por nem sempre serem postos em prática pelo aluno.

A citação do livro de Antônio de Almeida Oliveira, ao apontar para o tema do amor, afirma que existem objetos da leitura que são amados (os livros de literatura) e outros que são odiados (os livros de ciências). Notemos que, tendo em vista a função da leitura à época - qual seja, ilustrar -, o autor

3 Educador maranhense, que foi também advogado, jornalista, deputado geral e presidente de província. Ou seja, um homem de muitas ideias, como é apresentado no prefácio à edição de 2003. Diria, para ser fiel ao seu pensamento, um homem ilustrado, conforme o modelo do século XIX. 
expressa a sua indignação diante desse amor inútil, dado que não ilustra, não instrui, não torna o homem sábio, e esta seria a função da educação, segundo seu ponto de vista. Essa citação demonstra, então, que o texto literário nem sempre teve o estatuto que hoje possui.

Retomo essa questão para, mais uma vez, relacionar esses dizeres. Lembremos que, diferente de Antônio de Almeida Oliveira, os professores lamentam o fato de os alunos não gostarem do texto literário. Nesse sentido, esses dizeres revelam, cada um a seu modo, que há sempre uma valoração em relação ao objeto da leitura, explicitando a distinção entre boas e más leituras, e demonstrando que, do ponto de vista histórico, elas nem sempre são as mesmas.

Acredito que é preciso aprofundar essa discussão e tentar entender as consequências teóricas dessas formulações. Talvez uma possibilidade seja verificar que o verbo ler, para além de sua acepção intransitiva, liga (une, relaciona), numa mesma estrutura sintática, o sujeito e o objeto da leitura, ainda que às vezes esses lugares sintáticos estejam vazios (SOUSA, 2009). Essa é uma relação complexa que põe em jogo outras peças desse xadrez. Para tentar problematizar essa questão, transponho (parafraseio) uma formulação foucaultiana (FOUCAULT, 1996, p.9) sobre o discurso para a situação de leitura: Não é qualquer um que lê qualquer coisa, em qualquer lugar, de qualquer maneira, a qualquer momento, por qualquer motivo. A indeterminação incansavelmente repetida embaralha o jogo. Por um lado, ler reclama um sujeito da leitura (os leitores) que, dependendo do objeto da leitura (os textos), não pode ser qualquer um. Por sua vez, o objeto da leitura reclama/ exige, além de sujeitos específicos, modos de ler, que são constrangidos (delimitados ou limitados) por regras sociais, culturais, enfim, históricas. Por outro lado, seguindo as formulações de Michel de Certeau (1994), diríamos que o sujeito da leitura escolhe objetos que fogem a essas restrições e faz com eles o que não está na ordem da leitura considerada correta, ideal. Não entraremos nesses meandros, mas essa é uma questão a investigar.

Em estudo que tem como foco os tratados setecentistas, Abreu (1999) apresenta dois lados dessa questão: a crítica aos leitores de romance e o reconhecimento dos clássicos como obras que ilustram. Funcionamento semelhante ocorre hoje em dia: os clássicos, dentre os quais modernamente se incluem os romances, competem com leituras tidas como erráticas, a exemplo dos best-sellers. Vejamos como essa questão se apresenta nos depoimentos de professores quando eles falam sobre as leituras preferidas dos alunos:

P3: Eu creio que... (silêncio) eu tenho que pensar porque eu tenho que fazer uma geral de todos os alunos, mas eu acredito que de 
10 alunos, 3 leem, gostam do livro, obras clássicas, tá? O resto se prende mais às obras best-sellers, essas obras mais atuais né? Mas quando a gente propõe uma obra que é de fácil interpretação eles gostam, como por exemplo, "Coração roubado" né?

P4: $\mathrm{O} 3^{\circ}$ ano específico, eu não consigo identificar interesse por nenhum tipo de leitura que não fosse o gibi, o mangá, é o que eles gostam, já no fundamental que eu trabalho com a leitura aí eu percebo que eles têm interesse por essas obras como "Harry Potter", "O senhor dos anéis", "Crepúsculo", "Diário de uma princesa" então eles têm o contato com a leitura e com a literatura, essa leitura e literatura específica, não as obras do clássico, do cânone.

P1: Alguns, né? leem o livro da moda, principalmente aquele livro que fala /as meninas preocupadas muito com o mundo delas, o mundo da sexualidade, o mundo feminino num é? E procura essas autoras que fala da/ do relacionamento, daquelas coisas íntimas, que mais... de uma narrativa próxima dessa relação de desejo, amor né? Isso, as meninas leem, poucos homens leem aqui acolá um Harry Potter, os homens não gostam muito de ler não, eles tão lendo mais (risos) a moda agora é ler o jornalzinho da Correio4 "Já", vinte e cinco centavos né? Pra encontrar o quê? Num é nem leitura, mas vai em busca de mulheres peladas, num é? Jogos e sessões de assassinato.

P 5: [...] o que que esses jovens de hoje fazem? Assistem "malhação", num é? é malhaçãao, é "big Brother”, então não dão valor à leitura, quando leem uma revista, é revista destinada ao público adolescente, então numa linguagem sempre cheia de gírias, uma linguagem mais coloquial, então tudo que for um texto com uma linguagem mais culta, eles sentem dificuldades porque eles não conhecem.

Vejamos que, no primeiro depoimento, o livro é definido como “obras clássicas”. Em contrapartida, essas obras atuais, os Best-Sellers, são as leituras erráticas de hoje. Talvez fosse melhor dizer heréticas. Heréticas? Sim, se considerarmos o sentido etimológico da palavra: escolhas. Notemos que as obras mencionadas são as escolhas dos jovens de hoje: Harry Potter, o senhor dos anéis, Crepúsculo, Diário de uma princesa, mangás, gibis, revistas para o público adolescente, narrativas ("baratas" e sem nome) do mundo da sexualidade, leituras de meninas e de homens.

4 O professor refere-se ao jornal impresso Correio da Paraíba que circula com um encarte intitulado Caderno Já. Esse encarte pode ser vendido separadamente, por um custo bem menor que o do jornal. Trata-se de um caderno que coloca em circulação textos verbais e não verbais que podem ser considerados como jogos proibidos, em geral ligados a casos de violência urbana (assassinatos, prisões) e ao domínio da sexualidade, em especial, com cenas de mulheres seminuas ou nuas. 
É preciso ressaltar que, em todas as épocas, existem as leituras proibidas, não permitidas, as leituras marginais. Parece-me que quase sempre essas leituras revelam, na sua relação com o leitor, uma forma de amar, que, em princípio, remeteria ao desejo e ao prazer de ler de que falavam os professores inicialmente citados ${ }^{5}$. Ocorre que, enquanto leituras marginais, esse parece ser um desejo que não se deve explicitar, que é preciso conter. $O$ problema é que hoje essas leituras não são mais realizadas nas sombras, nos cantos escuros da casa (debaixo da cama, atrás dos móveis, escondidos no mato). Ou seja, os jovens alunos circulam às claras com os livros proibidos ("eu vejo meus alunos lendo"), em um espaço que, no discurso dos professores mencionados, não é próprio (a escola) a/para esses livros.

No contexto escolar, o confronto entre o comportamento leitor desses jovens e o discurso instituído - discurso competente, proferido por quem de direito - sobre a leitura correta, boa, adequada, coloca esses leitores sob um facho de visibilidade (FOUCAULT, 1987) que não é possível não ver. A escola vê essas leituras da moda, as desqualifica e, ao mesmo tempo, desqualifica o leitor, ao dizer que os alunos não leem, nem gostam de ler. $\mathrm{Na}$ verdade, o que esse discurso implicitamente recupera é a antiga divisão entre más e boas leituras, a partir de uma seleção que antecede o contato do leitor com o texto. Ou seja, é um discurso que reedita o embate, antes mencionado, entre o leitor e o objeto da leitura, entre a leitura que "ilustra" e a leitura que "distrai", tal como referida por Oliveira (2003).

Considerando que os alunos se subjetivam nessas leituras e que é preciso compreender essas formas de subjetivação que a sociedade atual e o jovem em particular revelam, irei me deter um pouco mais nessa questão.

Defendo que essas leituras entram na moderna configuração do conjunto dos jogos proibidos (ver MANACORDA, 1993) no interior das escolas. Classificadas a partir daquilo que as afasta dos clássicos, têm relação direta com os seus leitores. Aliás, essa relação gera uma contradição sobre a qual deveríamos refletir: seguindo a orientação sugerida nos depoimentos dos professores, são leituras de não leitores ou de quem não gosta de ler. Notemos que essa é uma estranha contradição, quando os próprios professores reconhecem que essas são leituras realizadas por e com prazer.

Nesse sentido, esses discursos revelam que a classificação dessas leituras não pode ser desvinculada da classificação dos seus leitores: considerados como imaturos, como veremos a seguir, e, portanto, incapazes de 
estabelecer escolhas adequadas ou de entender determinados textos, como sugerem os depoimentos citados, especialmente os de P3 e P5. Por isso, gostaria de considerar essa discussão também a partir de outro viés. Para demonstrar essa compreensão, recuperarei outras leituras.

\section{PRoblematizANDo os DiscuRSOS SOBRE O LEITOR: CONFRONTANDO LEITURAS}

Foucault (1987, p.126) defende: “[...] em qualquer sociedade, o corpo está preso no interior de poderes muito apertados, que lhe impõem limitações, proibições ou obrigações." É preciso mais uma vez acrescentar: o corpo também encontra modos de se esquivar a esse poder, de driblar a sua força, criando espaços de fuga. A título de exemplo, lembremos, conforme antes anunciado, que a função da leitura como divertimento e fruição foi quase sempre desqualificada, mas, apesar disso, sempre existiu (OLIVEIRA, 2003 e ABREU, 1999).

Defendo que esse discurso sobre a leitura, o texto e o leitor filia-se a uma tradição que remonta à construção do sujeito moderno. Certeau (1984) e Manacorda ([1989] 1996) consideram que Robinson Crusoé, o romance de Daniel Defoé, afirma-se como a metáfora da construção desse sujeito moderno. A ilha em Robinson Crusoé é a página em branco sobre a qual o personagem teria que produzir/construir sua história. Mas essa construção tem um modelo já dado: o homem civilizado que sabe ler e escrever, que domina as técnicas e os instrumentos do mundo moderno. Certeau (1984, p. 227), na bela leitura que faz desse livro, chama a atenção para o papel que a escrita assume, ao se referir ao momento em que Crusoé constrói o seu diário:

O romance combina os três elementos que eu distinguia: a ilha que demarca um lugar próprio, a produção de um sistema de objetos por um sujeito senhor, e a transformação do mundo 'natural'. É o romance da escritura. Aliás, em Defoe, o despertar de Robinson para o trabalho capitalista e conquistador de escrever a sua ilha se inaugura com a decisão de escrever o diário, de garantir-se assim um espaço de domínio sobre o tempo e sobre as coisas, e de constituir-se assim, com a página em branco, uma primeira ilha para aí produzir o seu querer.

Ressalto, porém, que, antes dessa escrita no papel, há uma escrita na "árvore" que orienta o "desorientado naufrago" em busca da normalidade para o mundo selvagem (marginal) no qual foi jogado: a construção de um calendário. Leiamos o trecho: 
Depois de estar ali dez ou doze dias, ocorreu-me que perderia a noção do tempo por falta de livros, papel e tinta e sequer distinguiria o sábado dos dias úteis. Para evitá-lo, fiz um poste em forma de cruz, que cravei no local onde pela primeira vez pisara a terra, e gravei nele com minha faca em letras maiúsculas "Cheguei a esta praia a 30 de setembro de 1659". (DEFOE, [1719] 1996, p. 73). (grifos nossos)

Observemos que livros, papel e tinta aparecem nessa narrativa com uma função bem específica: orientar o sujeito espacial e temporalmente e recriar a normalidade perdida. Na ausência desses instrumentos para a escrita, o naufrago recupera (do passado) outros instrumentos: a madeira e a faca que naquele momento servem ao propósito desejado: orientar-se, encontrar-se no tempo.

Voltando ao diário, há outras pegadas que também nos ensinam lições. Robinson Crusoé relata que, numa de suas voltas ao navio que naufragou (como se fosse uma volta ao seu passado), encontra ferramentas adequadas para essa orientação no novo mundo:

Em particular, pena, papel e tinta, diversos objetos pertencentes ao capitão, ao imediato, ao artilheiro e ao carpinteiro, tais como três ou quatro bússolas, instrumentos matemáticos, relógios de sol, lunetas, cartas e livros de navegação, que trouxe para a terra sem saber o que me seria útil ou não. Encontrei também três excelentes bíblias que vieram para mim da Inglaterra e que eu tivera o cuidado de colocar em minha bagagem; alguns livros portugueses, entre eles dois ou três de orações papistas e vários outros que guardei cuidadosamente. (DEFOE, [1719], 1996, p. 73-74)

A madeira e a faca, enquanto "ferramentas" para a escrita, voltaram para o passado a que já haviam sido relegadas. o sujeito, munido de artefatos do mundo "civilizado" (a bússola, o papel, o tinteiro e todos os instrumentos mais elaborados de trabalho), inscreve o mundo sem esquecer os preceitos da primeira escrita (a bíblia que ele também trouxe do navio) e as orações papistas que permitem (auxiliam a) classificar as coisas do mundo selvagem a partir de princípios do bem e do mal.

Nós continuamos organizando o mundo a partir desse parâmetro: de um lado o que é bom; do outro, o que é ruim. Nessa perspectiva, afirmaria, retomando Pêcheux (1983), que recorremos à separacão ancestral entre o alimento e o excremento. É preciso, contudo, lembrar que essa segregação é sempre estabelecida a partir de um ponto de vista. Hoje, parece que o discurso da leitura permissiva aparece atravessado pelo discurso da não leitura ou da desqualificação da leitura e do leitor. Por exemplo: ora afirma-se que 
os jovens não leem; ora que o que eles leem não tem valor, entendido, aqui, como aquilo que poderia construir (inclusive moralmente) esses sujeitos. Discursivamente, os atos de negar ou desqualificar a existência dessas leituras e de seus leitores possuem um funcionamento homólogo: ordenar e validar o discurso sobre as "boas" leituras.

Seguindo ainda a leitura de Defoe, diria que as leituras não autorizadas (aqueles que estão à margem do cânone estabelecido) são o rastro de Sexta-feira (o selvagem, o indomado) sobre a areia da ilha que, pelo menos momentaneamente, desestabiliza o mundo de Robinson Crusóe:

Certo dia, por volta das doze horas, indo visitar meu bote, fiquei extremamente surpreso ao descobrir na praia a marca de um pé descalço perfeitamente visível. Foi como se um raio houvesse me atingido, ou como se tivesse visto uma aparição. (DEFOE, [1719], 1996, p. 172) (grifos nossos).

É certo que, enquanto rastro na areia, ele não se fixa totalmente (apaga-se com um leve movimento do vento ou da onda sobre a areia da praia), mas, ainda assim, desestabiliza: "Não dormi aquela noite" (DEFOE, [1719], 1996, p. 173), afirma o aturdido personagem. Depois desse acontecimento, Robinson terá que construir estratégias para tornar visivel o dono do pé descalço, domar/dominar esse outro sujeito e enquadrá-lo à sua ordem (FOUCAULT, 1987 e 1996).

Em alguns momentos, procedimento semelhante ocorre com as leituras dos alunos: acolhe-se esse rastro (as leituras permissivas), tentando (in)formá-lo na/à ordem do discurso acerca da leitura correta e boa, conforme se verifica no depoimento a seguir:

P1: Acho que / tem uns alunos meus que estão lendo estes Best-Sellers aí de uma escritora, se num me engano uma romena aí, sucesso, tão lendo aí, tranquilo, termina já tá no outro. Outros tão lendo Harry Potter e eu deixo, Parabéns! eu dou elogio num é obrigado a só ler literatura não, primeiramente vamos deixar ler qualquer texto, pegar o gosto da leitura aí depois ter o hábito de ler as boas obras literárias. (grifos nossos)

Vejamos que, segundo o ponto de vista desse professor, a leitura preferida dos alunos - a boa leitura para eles, aquela que, na visão do professor, é sucesso, mas não é literatura - aparece como uma concessão (eu deixo!), porque ela pode ajudar a "pegar o gosto da leitura". Além disso, parece que esse discurso dubla a concepção de leitura refletida nos ensina- 
mentos de Antonio de Almeida Oliveira ([1873] 2003), na medida em que a maneira correta de ler também não admite a fruição; ela exige antes que se contenham os sentimentos, e se busque um ensinamento. Ou seja, diríamos que hoje a leitura está confinada a uma função bem específica, como afirma outro professor:

P6: [...] e a função da leitura na realidade é essa né? alertar né as pessoas, de trazer uma certa consciência né? de problemas políticos né? inclusive eh problemas da existência humana num é? O escritor quando escreve ele tem um propósito né? de atingir a alma né? de alertar, tem uma questão pedagógica por trás da arte. (grifos nossos)

Essa função pedagógica, ligada à instrução do sujeito leitor, à formação do cidadão - para citar uma referência comum em documentos oficiais, a exemplo dos Parâmetros Curriculares Nacionais e das Orientações Curriculares Nacionais para o Ensino Médio -, ajuda a selecionar e hierarquizar os bons e maus livros, os bons e maus leitores.

Há professores, contudo, que, embora refletindo o discurso da concessão das leituras, apresentam reflexões que encaminham para outros lugares teóricos sobre a leitura. É isso o que se observa no depoimento a seguir:

P7: [...] as pessoas falam muito que os adolescentes não leem, eu inclusive tenho um projeto aqui na escola que é um projeto de leitura "o que você está lendo?" inclusive está afixado a quantidade de alunos que leem e pra minha surpresa, os alunos leem e leem muito inclusive, leem muito. O que eles tem... eh o que eles não gostam é da leitura imposta, da leitura imposta, num é? da leitura imposta e existe uma certa resistência com relação aos clássicos. A gente tem uma resistência com relação aos clássicos, você pega uma turma a partir de 50 alunos, 10 dos alunos leem o livro. Se você deixa eles livres pra fazer as leituras, você tem vários autores, diversos inclusive e eles se predispõem a ler e claro a gente sabe que não é a grande maioria, mas leituras que desmistificam muitas ideias hum... a espessura dos livros num é? "Lua nova", "Crepúsculo", "Eclipse”, eles estão lendo demais. Aí você diz assim: ah mas é uma leitura que num... é interessante, é! É uma leitura que o vocabulário eleva, o nível de de compreensão de certa forma, o aluno começa a refletir, começa a pensar né? "Marley e eu" que mais... os clássicos da literatura num é? Jô Soares tá sendo muito lido pelos meninos, surpreende, de vez em quando, entre esses livros aparece o clássico Graciliano Ramos, o próprio Machado de Assis no $1^{\circ}$ ano.

Então quando a idéia vem de cima pra baixo ela é mais complicada, eu sempre tô trazendo uma inovação porque eu sempre começava 
com os livros indicados pela Universidade Federal e aí esse ano a gente começou perguntando o que eles gostariam de ler, o que eles estão lendo e aí a gente teve um resultado bem maior, porque a gente não começou de cima pra baixo mas de baixo pra cima, nessa hierarquia, então eles começaram a interagir mais né? Eles fizeram fichas de leituras, eles preenchem, entregam, há uma quantidade... só esse ano eu tenho mais ou menos umas 500 fichas nas escolas todas feitas pelos alunos. (grifos nossos)

Nesse depoimento, gostaria de destacar algumas questões que remetem para esses lugares teóricos sobre o ensino da leitura: primeiramente, vejamos que o professor reconhece (com surpresa, é certo!) como é falho o discurso de que o aluno não lê; em segundo lugar, que para esse aluno leitor não importa a quantidade de páginas a serem lidas ("a espessura dos livros"), mas a sua relação com texto; em terceiro lugar, que há uma "resistência com relação aos clássicos" e aos livros impostos e em quarto lugar, o reconhecimento, ainda que também sob o signo da surpresa (surpreende, de vez em quando, entre esses livros aparece o clássico Graciliano Ramos, o próprio Machado de Assis no $1^{\circ}$ ano), de que os alunos também leem os clássicos.

Mas, há também nesse depoimento a retomada de outra questão teórica: a concepção de que a leitura sempre tem que "servir" para alguma coisa - elevar o vocabulário, o nível de compreensão - e sempre precisa ser, de algum modo, controlada, a partir de outras tarefas escolares, como preencher fichas de leitura. Essa parece ser uma condição à qual a leitura na escola está constrangida e da qual não pode fugir, dada a própria condição da própria Escola, enquanto instituição promotora do saber e caracterizada pelos processos de ensino e de aprendizagem.

Nesse contexto, a noção de instrução atrelada à função primeira da leitura na escola - ler para aprender a ler e escrever - acaba sendo incorporada a esse discurso. Voltemos, então, a Abreu (1999) e à sua leitura dos tratados sobre a leitura nos séculos XVIII e XIX, quando ressalta a função da leitura e a sua relação com a escrita. Ou seja, nesse período, a maneira correta de ler estava diretamente relacionada à formação de um modelo para escrita: Ler, reler, anotar, registrar para memorizar; entender, reduzir, desenvolver, comparar, julgar. Esses são modos de ler, operações de leitura que ela destaca em vários tratadistas. São modos de ler que relacionam à leitura a uma função de instrução: ler para conhecer, ler para saber escrever. Vejamos que, também nesse momento, o ler pelo puro prazer de ler não fazia parte da "maneira correta de ler".

Considerando os modos de ler, notemos que vários dos professores afirmam que a leitura do texto literário requer tempo, dedicação e reclamam que sentem nos alunos de hoje "falta de paciência, de um sentimento de aprender, ouvir né? Alguma coisa, ele não tem paciência, então é difícil como 
professor a gente quer tirar ele da sala de aula, apresentar algo inovador, diferente, uma aula mais atrativa, torna-se quase a mesma coisa porque eles são impacientes, inquietos" (Professor 1), e de maturidade para a leitura dos clássicos "porque ele não tá acostumado no dia a dia ver aquilo e sim pegar uma notícia, uma reportagem, até na internet mesmo, eles tem acesso a algo mais objetivo, então a dificuldade de lidar com o gênero literário é muito mais...complicado do que você pegar um gênero textual mais claro e objetivo" (Professor 1). Já que os professores apontam e lamentam essa falta de maturidade e de paciência, é importante citar nesse momento alguns trechos dos depoimentos em que os eles dizem como desenvolvem o trabalho de leitura do texto literário em sala de aula.

P2: [...] eu trabalhei trechos de Marília de Dirceu e de Cartas chilenas, explicando assim o contexto, o significado de cada um pra quando eles fossem ler sozinhos (...) estivessem sabendo do que se tratava, porque o poema já é difícil, se você vai ler um poema sem saber do que se trata né? Aí eu expliquei a parte da contextualização né? tanto de Marília como o do/de Cartas Chilenas. Coração Roubado foi só a leitura de um ou outro texto, pedindo que eles lessem tudo, porque eu digo: olhe, a leitura não é só pra o vestibular né? Vocês têm que ler o livro pelo prazer de ler, agora vocês vão juntar as duas coisas: vão ter o prazer de ler e de repente vai cair um texto e vocês/ não vai ser surpresa né? Uma coisa é você pegar um texto que você já leu em casa, já esmiuçou, já viu o vocabulário e outra é você pegar um texto pela primeira vez né? [...] Aí... e outro livro a gente fez em forma de teatro aqui a gente tem o professor de geografia de manhã que é diretor de teatro (...) então no começo do ano ele montou o "Judas em sábado de Aleluia", ele montou a peça e a gente levou todo turno da tarde e da manhã. (grifos nossos)

P5: eles não gostam na grande maioria das vezes, se a obra é um pouco mais nova eles conseguem entender, quando é uma obra do século dezessete, do século dezoito há uma dificuldade muito grande, então que que eu faço? eu sempre começo minha/quando eu vou abordar uma obra, então eu falo um pouco sobre o autor daquela pra que eles entendam muitas vezes a relação do autor/ da vida do autor com que ele escreve

E: contextualizando...

P5: contextualizando essa parte, depois eu falo sobre as ideologias da época e mostro a obra, então quando/ eu faço a leitura do primeiro, segundo, terceiro capitulo em sala de aula junto com eles, aí paro aquele capítulo e explico, aí eu mostro a linguagem, que a linguagem é daquela época, que ela não pode ser atualizada porque a obra vai perder toda essência, num é? e faço um resumo do/do conteúdo da obra em si e aí muitas vezes eles/surte um pouco de efeito, alguns terminam lendo realmente a obra toda, certo? e nós 
sempre vamos abordando/e como nós cobramos né? em prova, então muitas vezes eles terminam lendo, aí eles se encantam, vem a dificuldade da leitura, aqueles que terminam de ler, vem a dificuldade da leitura, mas conseguem terminar muitas vezes a obra é apaixonante [...](grifos nossos)

P6: [....] eles se preocupam muito com resumo que virou uma prática de alunos do ensino médio que vai fazer o vestibular, eles não querem ler a obra eles querem apenas o resumo, mas além de levar o resumo eu levo alguns artigos que eu procurei na internet de doutorandos, até de professores doutores mesmos que abordam outras questões relevantes dessas obras literárias, por exemplo no Pagador de promessas eu trabalhei um artigo da USP sobre o sincretismo religioso em Dias Gomes. Então eu sempre procuro levar uma outra ideia, uma ponte pra que não fique preso a um livro que eles não têm.

P7: Eh... de forma geral a recepção dos alunos em relação ao texto literário tem uma certa resistência, tem uma certa resistência, entendeu? [...] uma leitura mais densa como a de Machado de Assis, por exemplo, os alunos têm uma certa resistência, isso é uma verdade entendeu? o hábito da leitura, o dia a dia embora eu tenha exposto que o aluno lê, mas essa essa leitura dos clássicos, uma leitura mais reflexiva ainda leva um trabalho bem maior, bem maior mesmo. Então vez por outra a gente indica um filme relacionado ao conteúdo, pra ver se desperta, é um caminho meio que inverso, o aluno deveria ler o livro pra ver o filme, hoje a gente tem que despertar de outra forma pra ver se a gente consegue informação do youtube pra ler o livro num é? Então tem a ideia do que é poético e tem ideia de como você atraí-lo, acho que os recursos áudios-visuais hoje são fundamentais pra despertar no aluno uma leitura quando ele vê um filme como "Memórias Póstumas de Brás Cubas" ele se interessa pra ver o livro, quando ele vê um filme como (...) ele se interessa pra ler "Dom Casmurro" então é meio que o caminho inverso, embora muita gente questione num é? Acha que a ideia perfeita/ você ler o livro pra depois ver o filme, seria o ideal, mas pra despertar hoje a garota a gente tem que... ter algum recurso senão fica muito difícil né? (grifos nossos)

Explorar o contexto, esmiuçar o texto, ver o vocabulário, ler trechos da obra, mostrar a linguagem, falar sobre a vida do autor, fazer um resumo do conteúdo da obra, levar textos que falam sobre (leram) a obra; fazer uma peça, ver um filme são várias das estratégias apresentadas pelos professores para aproximar os alunos dos textos literários. Essas estratégias recuperam os modos mais comuns (fórmulas!) de se ler o texto literário na escola. E muitas vezes, surte um pouco de efeito. Muitas vezes, o professor tem que pegar o caminho inverso, recorrendo a outras linguagens mais próximas 
dos alunos. Ou seja, todos os professores parecem dizer que fazem a sua parte, mas não conseguem alcançar esse leitor insatisfeito e impaciente. Torna-se relevante registrar que, explicita ou implicitamente, todos acabam confirmando - mesmo quando negam a evidência - que os alunos leem e que a leitura pode ser apaixonante.

Há várias outras questões nesses depoimentos que poderiam ser ressaltadas. Mas, é preciso concluir, e prefiro concluir apontando algumas reflexões que esses últimos depoimentos sugerem. Para concluir, então, talvez a solução seja enunciar um título às avessas, o qual dribla a necessidade do gênero (artigo) e demonstra a insatisfação do sujeito que tem que concluir a escrita para que seu texto convoque leitores.

\section{NÃO HÁ CONCLUSÃO, MAS É PRECISO CONCLUIR...}

Parece que um dos dilemas que esses depoimentos revelam remete para a própria natureza da leitura do texto literário. Em princípio, notemos que esse objeto da leitura (o texto literário) liga-se a um dos sentidos do verbo ler que é difícil de ser administrado no interior de uma instituição de ensino. Dito de outro modo, ensinar a ler (função atribuída à escola) confronta-se com a ideia de prazer, requerida pela literatura. A ação de ensinar a ler, ou seja, o "ensinamento", diferentemente da "leitura desejante" de que fala Roland Barthes (1987), supõe em geral um trabalho - às vezes maçante e repetitivo - de enformamento do olhar do leitor, para enxergar aspectos que seriam capazes de conduzir à leitura correta. Por fim, espera-se sempre que esse trabalho resulte em encantamento, seja capaz de fazer o aluno gostar de ler, sentir-se apaixonado pela leitura.

É preciso perceber que há algo difícil nessa tarefa, dado que encantamento, paixão, prazer são sentimentos que não se ensinam, aprende-se vivendo e, nesse caso, em princípio, lendo. E há mais: lendo para chegar ao final e dizer também que não gostou do que leu, que não sentiu prazer nenhum. Considerando especificamente o texto literário, lembro as palavras de Daniel Pennac (1993, p. 13):

O verbo ler não suporta o imperativo. Aversão que partilha com alguns outros: o verbo 'amar'... o verbo 'sonhar'... Bem é sempre possível tentar, é claro. Vamos lá: 'Me ame!' ‘Sonhe!' Leia!' 'Leia logo, que diabo, estou mandando você ler!'.

Imaginemos, então, a formulação: leia, goste de ler, sinta prazer em ler! Complicado! A obrigação de ler, aliás, já foi lembrada pelo professor 
7, citado anteriormente, como empecilho à leitura: "O que eles tem... eh o que eles não gostam é da leitura imposta, da leitura imposta, num é?". Lembro, entretanto, que mais complicado do que a imposição da leitura é a premissa de que todos têm obrigação de gostar de ler, obrigação mais enfática quando se trata de obras tidas como clássicos da literatura, as quais não suportam o desamor.

É preciso reconhecer, sem sermos ingênuos, que a leitura impõe-se hoje em nossa sociedade como uma obrigação. É preciso ler: slogan moderno! Se essa obrigação, decorrente de uma necessidade das nossas (novas) práticas sociais, pode ser desenvolvida com prazer, melhor. Claramente, $o$ que estou propondo como discussão é que a escola tem o dever, a obrigação de ensinar a ler, de proporcionar o acesso aos livros, dentre os quais os clássicos da literatura. Contudo, o prazer é atributo do leitor, que deve ser cativado para que no processo de ensino e de aprendizagem o prazer se faça presente ("dê o ar da graça").

Além disso, é preciso que nós, professores, reflitamos sobre as imagens de leitura e de leitor que nós construímos e/ou reproduzimos e sejamos capazes de entender como elas evidenciam diferentes desafios para nós mesmos. O que é uma boa ou má leitura? Essa é uma avaliação que depende de quem lê, do quê e para quê (ou mesmo para quem) lê. Às vezes, não somos capazes de perceber como o nosso olhar sobre o aluno é enviesado, como nossas lentes são embaçadas. Nesse sentido, mais uma vez, burlando as regras de uma conclusão, deixo a título de reflexão dois depoimentos que se contrapõem e que suscitam novas discussões:

P8: os alunos? Eles leem? Revista de informática, é o que eu sempre estou vendo, procuram ler muito revista de informática, procurando assim alguma coisa, resumos né? Uma coisa que a gente entrega e tem que ser mínimo, mínimo que é pra num dar trabalho pra eles, a leitura deles é muito assim, eles são leitores realmente de cerveja: chegou, tira a tampa, vai embora logo. (grifos nossos)

P7: Você começa a gostar da leitura quando a leitura começa a falar alto, aí você se interessa. Quando o livro começa a ler você aí você se interessa pela leitura, quando o livro não diz nada sobre você geralmente fica difícil você gostar de ler... (grifos nossos) 


\section{REFERÊNCIAS}

ABREU, Márcia (Org.). Leitura, história e história da leitura. Campinas: ALB; Mercado de Letras, 1999.

BARTHES, Roland. O rumor da língua. Tradução de António Gonçalves. Lisboa, Portugal: Edições 70, 1987.

CERTEAU, Michel de. A invenção do cotidiano: 1. Artes de fazer. Tradução de Ephraim Ferreira Alves. 2. Ed. Petrópolis: Vozes, 1994.

CHARTIER, Roger. Inscrever e apagar: cultura escrita e literatura, séculos XI-XVIII. São Paulo: Ed. UNESP, 2007.

. Práticas de leitura. São Paulo: Estação Liberdade, 2001.

. A ordem dos livros: leitores, autores e bibliotecas na Europa entre os séculos XIV e XVIII. Brasília: Editora da UNB, $1999_{\mathrm{a}}$.

. A aventura do livro: do leitor ao navegador. São Paulo: Ed. da UNESP, $1999_{\mathrm{b}}$.

DEFOE, Daniel. [1719]. As aventuras de Robinson Crusoé. Tradução de Albino Poli Jr. Porto Alegre: L\&PM, 1996.

FOUCAULT, Michel. Vigiar e punir: nascimento da prisão. Tradução de Lígia M. P. Vassalo. 5. ed. Petrópolis: Vozes, 1987.

A ordem do discurso. Tradução de Laura Fraga de Almeida Sampaio. 2. ed. São Paulo: edições Loyola, 1996.

LAJOLO, Marisa e ZILBERMAN, Regina. A formação da leitura no Brasil. São Paulo: Ática, 1999.

MANACORDA, Mario Alighiero. História da educação: da antigüidade aos nossos dias. Tradução de Gaetano Lo Monaco. 5. ed. São Paulo: Cortez, 1996.

PÊCHEUX, Michel. O discurso. Estrutura ou acontecimento. Tradução de Eni P. Orlandi. 2. ed. Campinas, SP: Pontes, 1997.

PENNAC, Daniel. Como um romance. Tradução de Leny Werneck. Rio de Janeiro: Rocco, 1993.

OLIVEIRA, Antônio de Almeida. [1973] O ensino Público. Brasília: Ed. do Congresso Nacional, 2003.

SOUSA, Maria Ester Vieira de. Leituras de professores e alunos: entre o prazer e a obrigação. In: ENCONTRO INTERNACIONAL TEXTO E CULTURA, 2008. Anais... Fortaleza: UFC, 2008.

. Desnaturalizando os discursos sobre a leitura. In: CONGRESSO INTERNACIONAL DA ABRALIN, 4., 2009. Anais... João Pessoa: Idéia, 2009. p. 2267-2271.

Submetido em: 07/11/2013

Aceito em: 17/04/2014 